\title{
Does Providing Clinical Care for Trauma Patients have a Positive Effect on Physicians' Perspective on Child Passenger Safety?
}

\author{
Travma Hastası Bakıyor OImanın Hekimler Üzerine Çocuk Araç Güvenliği Konusunda \\ Olumlu Bir Etkisi Var mı?
}

\author{
(1) Aykut Çağlar ${ }^{1}$, (1) Figen Çelebi Çelik ${ }^{2}$, Anıl Er ${ }^{1}$, (1) Emel Ulusoy ${ }^{1}$, (1) Utku Karaarslan³ ${ }^{3}$ (1) Fatma Akgül1 ${ }^{1}$, (1) Hale Çitlenbik ${ }^{1}$, \\ (1) Başak Bayram4, (1D Durgül Yılmaz¹, (1) Murat Duman'1 \\ ${ }^{1}$ Dokuz Eylül University Faculty of Medicine, Department of Pediatric Emergency Care, Izmir, Turkey \\ 2Dr. Behçet Uz Children's Hospital, Clinic of Pediatrics, Izmir, Turkey \\ ${ }^{3}$ Dokuz Eylül University Faculty of Medicine, Department of Pediatric Intensive Care, Izmir, Turkey \\ ${ }^{4}$ Dokuz Eylül University Faculty of Medicine, Department of Emergency Medicine, Izmir, Turkey
}

\section{Abstract}

Introduction: Motor vehicle crashes are the most common cause of the mortality in the pediatric population. Preventive strategies are the best approach to reduce mortality and morbidity due to motor vehicle crashes. Since parents mostly refer to them for guidance, doctors should have a high level of knowledge and awareness to increase the usage of car safety seats. We thought that providing care for trauma patients could have a positive effect on the physicians' awareness and knowledge level. Based on this, we aimed to assess the awareness and knowledge of pediatricians and emergency physicians and trauma doctors.

Methods: An electronic survey consisting of 23 questions was prepared. Demographic features, awareness and knowledge level of the physicians were assessed on three sections. Five suggestions in the guideline of the American Academy of Pediatrics were used to assess physicians' knowledge level. The respondents were grouped as those providing clinical care for trauma patients and those do not.

Results: The questionnaires were sent to 641 physicians and 323 who completed the questionnaire were included in the study. One hundred and fourteen (35.3\%) of the respondents were providing clinical care for trauma patients. One hundred ninety (59.2\%) respondents had children. Majority of the physicians had a satisfactory level of knowledge about car safety seat (CSS). The number of respondents reported having adequate self-awareness was found statistically significantly higher in the groups of doctors who have children and provide clinical care for trauma patients ( $p<0.01$ and $p=0.01$, respectively). However, there was no significant difference in the level of knowledge between non-providers and providers of clinical trauma care $(p>0.05)$. Interestingly, the knowledge level in physicians who had children was statistically significantly lower than in those with no children $(p<0.01)$.

Conclusion: Our survey revealed that physicians who provide clinical care for trauma patients think they have a high level of knowledge about

\section{Öz}

Giriş: Ülkemizde ve dünyada, çocukluk çağında en önemli Ölüm sebebi, motorlu araç kazalarıdır. Önleyici stratejiler ile motorlu araç kazalarına ikincil mortalite ve morbididte önemli ölçüde azalmaktadır. Araç güvenliği kullanımının arttırmak için ailelerin ve en sık başvurulan bilgi kaynağı olan hekimlerin yüksek bilgi düzeyine ve farkındalığa sahip olması gerekmektedir. Biz, travma hastası bakıyor olmanın hekimlerin bilgi düzeyi ve farkındalığı üzerine olumlu etkisi olabileceği fikrinden yola çıkarak çocuk hekimleri, acil hekimleri ve travma karşılayan hekimlerin çocuk araç koltuğu kullanımı hakkında farkındalığını ve bilgi düzeyini ortaya koymayı amaçladık. Yöntemler: Çalışma için 23 sorudan oluşan bir anket formu elektronik olarak hazırlandı. Anket formu üç bölümden oluşturuldu. Bu üç bölümde demografik veriler, çocuk araç güvenliği hakkında farkındalığı ve bilgi düzeyi sorgulandı. Üçüncü bölümde Amerikan Pediyatri Derneği'nin beş temel önerisi sorularak, bilgi düzeyinin ölçülmesi hedeflendi. Hekimler, travma hastası karşılayan ve karşılamayanlar olarak iki grupta karşılaştırıldı.

Bulgular: Çalışmanın başında 641 anket formu elektronik olarak hekimlere gönderildi. Tüm katılımcıların 114'ü $(\% 35,3)$ travma hastası karşılıyordu. Yüz doksan bir $(\% 59,2)$ hekimin çocuğu vardı. Kendi bilgi düzeylerini orta derecede görenlerin sayısı travma bakan ve çocuğu olan hekimlerde istatistiksel olarak anlamlı şekilde yüksekti (sırasıyla; $p<0,01$ ve $p=0,01$ ). Buna karşın travma bakan hekimlerin bilgi düzeyinde anlamlı yükseklik saptanmadı $(p>0,05)$. Il ginç olarak çocuğu olanların ise bilgi düzeyi grubun kalanına göre daha düşüktü $(p<0,01)$. Sonuç: Bu anket çalışması, travma hastası bakan hekimlerin çocuk araç güvenliği konusunda yüksek bilgi düzeyine sahip olduğunu düşünmesine karşın aslında bilgi düzeylerinin diğer hekimler kadar olduğunu ortaya koymaktadır. 
CSS. Unfortunately, their knowledge level was low as other physicians in the study group.

Keywords: Child, car safety seats, emergency medicine, motor vehicle, trauma
Anahtar Kelimeler: Çocuk, araç koltuğu, acil tıp, motorlu araç, travma

\section{Introduction}

Motor vehicle crashes (MVC) are the most common cause of pediatric mortality in developed countries. Preventive strategies are the best approach to reduce mortality and morbidity due to MVCs. Especially in children, increasing the proper use of child passenger restraints and car safety seats (CSS) is one of the key steps to reduce MVC-related deaths and injuries. The Center for Disease Control and Prevention (CDC) has reported that a $15 \%$ decrease in MVC-related deaths was achieved between 2007 and 2015. ${ }^{1}$ Unfortunately, in Turkey, awareness and knowledge of parents about CSS are very low. ${ }^{2,3} \mathrm{~A}$ few key elements are needed to increase the use of CSS such as making strict policies, laws and campaigns about the use of CSS and restraints, and increasing level of awareness pediatricians and parents. Although there are many studies in the literature focusing on parents' awareness and knowledge, there is a limited number of studies about the knowledge of pediatricians. ${ }^{47}$ The study population in these studies was mostly office-based doctors and community pediatricians. However, emergency and intensive care doctors, who witness variety of injuries and even death due to MVCs, were included in a limited number of studies. ${ }^{8,9}$ We hypothesized that witnessing injuries due to MVCs may have a positive effect on the doctors' knowledge and awareness. Therefore, we designed a questionnaire study to assess the level of self-reported awareness and knowledge of pediatricians and emergency physicians and trauma doctors.

\section{Materials and Methods}

A survey with a total of 23 questions was designed electronically. The survey comprised three different kinds of questions. The first section of the questionnaire targeted demographic data of physicians, while the second section targeted self-reported awareness of physicians, and the last section queried physicians' knowledge about child passenger safety (including CSSs and booster seats) with 5 questions which were based on recommendations issued by the American Academy of Pediatrics (AAP) (Table 1). ${ }^{10}$ The questionnaire was sent to physicians via e-mail. Completion of the questionnaire form by responders was accepted as written consent. All completed surveys were included in this study and all incomplete surveys were excluded. Physicians were grouped according to whether they were involved in the care of trauma patients or not. Physicians' knowledge was classified according to the number of correct answers (excellent: 5, very good: 4 , satisfactory: 3 , borderline: 2 , and poor: 1 and 0 correct answers). Physicians' awareness was classified as "excellent, very good, satisfactory, borderline and poor. This study was approved by the Dokuz Eylül University Medicine Clinical Research Ethics Committee (report number: 2274-GOA; 2015/21-07). No financial support was received for this study.

\section{Statistical Analysis}

Predictive Analytics Software version 23.0 (IBM Corp. Armonk, NY, USA) was used to analyze the data. The quantitative data were described as means and standard deviation. A chisquare test or Fisher's exact test was used to compare the two groups of those who care for trauma patients or who do not. A p value of less than 0.05 was considered statistically significant.

\section{Results}

The questionnaire was sent to 641 physicians. 323 who completed surveys were included in this study. The male/ female ratio was $1: 1,8$. The mean age of the participants was

\begin{tabular}{|c|c|}
\hline $\begin{array}{l}\text { Practice } \\
\text { recommendations }\end{array}$ & \\
\hline 1 & $\begin{array}{l}\text { All infants and toddlers should ride in a rear-facing } \\
\text { CSS until they are } 2 \text { years of age or until they } \\
\text { reach the highest weight or height allowed by the } \\
\text { manufacturer of their CSS }\end{array}$ \\
\hline 2 & $\begin{array}{l}\text { All children } 2 \text { years or older, or those younger } \\
\text { than } 2 \text { years who have outgrown the rear-facing } \\
\text { weight or height limit for their CSS, Should Use } \\
\text { a Forward-Facing CSS with a harness for as long } \\
\text { as possible, up to the highest weight or height } \\
\text { allowed by the manufacturer of their CSS }\end{array}$ \\
\hline 3 & $\begin{array}{l}\text { All children whose weight or height is above the } \\
\text { forward-facing limit for their CSS should use a } \\
\text { belt-positioning booster seat until the vehicle lap- } \\
\text { and-shoulder seat belt fits properly, typically when } \\
\text { they have reached } 4 \text { feet } 9 \text { inches in height and } \\
\text { are between } 8 \text { and } 12 \text { years of age }\end{array}$ \\
\hline 4 & $\begin{array}{l}\text { When children are old enough and large enough } \\
\text { to use the vehicle seat belt alone, they should } \\
\text { always use lap-and-shoulder seat belts for optimal } \\
\text { protection }\end{array}$ \\
\hline 5 & $\begin{array}{l}\text { All children younger than } 13 \text { years should be } \\
\text { restrained in the rear seats of vehicles for optimal } \\
\text { protection }\end{array}$ \\
\hline
\end{tabular}


$34.07( \pm 6.20)$ years. Characteristic features of the physicians are summarized in Table 2. The self-reported awareness of CSS among the majority of physicians was satisfactory. The main source of knowledge about CSS was community forum web pages (32.9\%). However, the percentage using the AAP policy statement on CSS as a source of information was $10.3 \%$. Among physicians who had children, the use of the AAP as a knowledge source was significantly higher than in those who had no children $(p<0.01)$. However, in the group who had children, the use of the AAP for the knowledge source was lower than (23\%) the use of web forum pages (55\%). To assess public awareness of CSS, the most frequent suggestion was advertising campaigns (76.4\%). The other suggestions of the respondents are summarized in Table 3.

Among the participants, 191 (59.2\%) respondents had children and $90.6 \%$ of them had children under 13 years old. The respondents who had children had a higher awareness level than who did not have children $(p<0.001)$. Forty-one

\begin{tabular}{|ll|}
\hline \multicolumn{2}{|l|}{ Table 2. Characteristic features of the physicians } \\
\hline Features of physicians & $\mathbf{n}(\%)$ \\
Gender (Male) & $114(35.3)$ \\
Age (years)* & $34.0(6.2)$ \\
Number of children & \\
0 & $136(40.8)$ \\
1 & $106(32.8)$ \\
2 & $71(21.9)$ \\
$>3$ & $14(4.3)$ \\
Specialty & \\
Pediatrics & $251(77.7)$ \\
Pediatric emergency & $19(5.9)$ \\
Pediatric intensive care & $14(4.3)$ \\
Emergency medicine & $39(12.1)$ \\
Institution of the physicians & \\
Medical faculty & $146(45.2)$ \\
Research and training hospital & $101(31.2)$ \\
Public hospital & $55(17.0)$ \\
Private hospital & $21(6.5)$ \\
Physicians who care for trauma patient & $114(35.3)$ \\
Duration of working as a doctor & \\
$<5$ years & $211(65.3)$ \\
$5-10$ years & $58(17.9)$ \\
$11-20$ years & $41(12.6)$ \\
$>20$ years & $13(4.0)$ \\
*Values shown as mean \pm standard deviation) & \\
\hline
\end{tabular}

Table 3. Suggestions of the respondents about increasing public awareness of car safety seat

\begin{tabular}{|ll|}
\hline Suggestions of the respondents & $\mathbf{n}(\%)$ \\
\hline Advertising campaign & $247(76.4)$ \\
\hline Strict laws by the government & $151(46.7)$ \\
Visual media in public areas & $145(44.8)$ \\
\hline Inclusion in the curriculum in medical faculties & $119(36.8)$ \\
Giving out brochures & $65(20.1)$ \\
\hline Updating physicians via e-mail & $33(10.2)$ \\
\hline
\end{tabular}

(21.4\%) physicians had not used CSS and the main reason was that children refused to be seated in a CSS (24.3\%). Eight (19.5\%) physicians considered CSS unnecessary for their own children. Having a large family (14.6\%) was another excuse in the study group. Seat belt (37.7\%) was the most commonly used method to maintain safety of the children in the group who did not use CSS.

Five questions about CSS, which were suggested in the AAP guidelines, were directed to all respondents. The percentages of knowledge and awareness levels of all respondents and comparisons of knowledge and self-reported awareness levels of the groups are summarized in Table 4. Respondents who had children, or who provided clinical care for trauma patients considered their knowledge level satisfactory and The number of respondents reported having adequate self-awareness was found statistically significantly higher in the groups of doctors who have children and provide clinical care for trauma patients $(p<0.01$ and $p=0.01$, respectively). However, there was no significant difference in the level of knowledge between nonproviders and providers of clinical trauma care $(p>0.05)$.

Interestingly, the knowledge level of physicians who had children was statistically significantly lower than the rest of the participants $(p<0.01)$.

\section{Discussion}

According to the CDC reports, MVCs are still a leading cause of mortality, especially in the pediatric population. ${ }^{11}$ The most important development in decreasing mortality secondary to MVCs was widespread use of CSS. The reduced risk of death with CSS use in the pediatric population was expressly stated in previous reports. ${ }^{12,13}$ Increasing the use of CSS depends on the awareness of parents and also physicians. There are many studies in the literature that determined the awareness and knowledge of parents about CSS. $2,3,14,15$ The common result of these studies was that there was low utilization of CSS. Additionally, one of the striking results of previous studies is that doctors were the most common source of guidance for CSS.7,14,16 This data comes with questions; do doctors have satisfactory knowledge about CSS? Moreover, how often do doctors abide by the requirements of car safety for their own children? In the literature, there are few reports which assessed the knowledge of physicians about CSS. ${ }^{49,14,16}$

In our study, having children had a statistically significant effect on the doctors' awareness level as expected and this was in concurrence with previous studies. ${ }^{6,7}$ Probably being a parent makes doctors more sensitive about protecting their children, and encourages them to seek information about CSS. Despite all, interestingly, physicians who had children had lower knowledge levels and that was statistically significant. 
Table 4. Comparison of the physicians according to knowledge and self-awareness levels

\begin{tabular}{|c|c|c|c|c|c|c|}
\hline \multirow{3}{*}{ Answer categories } & \multicolumn{3}{|c|}{ Knowledge level* } & \multicolumn{3}{|c|}{ Self-awareness** } \\
\hline & \multicolumn{2}{|c|}{ Care of trauma patients } & \multirow{2}{*}{$\begin{array}{l}\text { All respondents } \\
n=323 \\
(100 \%)\end{array}$} & \multicolumn{2}{|c|}{ Care of trauma patients } & \multirow{2}{*}{$\begin{array}{l}\begin{array}{l}\text { All } \\
\text { respondents }\end{array} \\
n=323 \\
(100 \%)\end{array}$} \\
\hline & $\begin{array}{l}\text { Yes } \\
n=114(35.3 \%)\end{array}$ & $\begin{array}{l}\text { No } \\
n=209 \\
(64.7 \%)\end{array}$ & & $\begin{array}{l}\text { Yes } \\
n=114 \\
(35.3 \%)\end{array}$ & $\begin{array}{l}\text { No } \\
n=209 \\
(64.7 \%)\end{array}$ & \\
\hline Excellent & $2(0.6)$ & $0(0.0)$ & $2(0.6)$ & $1(0.3)$ & $1(0.3)$ & $2(0.6)$ \\
\hline Very good & $4(1.2)$ & $2(0.6)$ & $6(1.9)$ & $22(6.8)$ & $22(6.8)$ & $44(13.6)$ \\
\hline Satisfactory & $5(1.5)$ & $9(2.8)$ & $14(4.3)$ & $67(20.7)$ & $104(32.2)$ & $171(52.9)$ \\
\hline Borderline & $29(9.0)$ & $60(18.6)$ & $89(27.6)$ & $23(7.1)$ & $75(23.2)$ & $98(30.3)$ \\
\hline Poor & $74(22.9)$ & $138(42.7)$ & $212(65.6)$ & $1(0.3)$ & $7(2.2)$ & $8(2.4)$ \\
\hline
\end{tabular}

We associated this result with the public web forum pages which were the most commonly used source as a reference guide instead of the AAP guidelines.

Our hypothesis originated from an old saying "example is better than precept". We thought that trauma doctors would have high levels of knowledge but our results were not as expected. Our study revealed that doctors had low levels of knowledge about CSS which complies with previous studies. Additionally, many trauma doctors in our study considered their own knowledge satisfactory.

Morrongiello et al. ${ }^{17}$ defined the "teachable moment" which can sensitize parents in the moment after injury and can have a positive effect to ensure preventive strategies for own child. Previous studies ${ }^{8,9} \mathrm{w}$ that this phenomenon had no effect on doctors contrary to the effect on parents. Moreover, they may be desensitized because of witnessing injuries repeatedly. At the teachable moment, providing suggestions about CSS may be more efficient for parents. Zonfrillo et al. ${ }^{8}$ reported that although patients have enough time to obtain information about CSS, emergency physicians could allocate only a limited time to give information to parents in emergency settings because of overcrowded emergency department (ED). ${ }^{8}$ Majority of the respondents in our study suggested that the use of visual media or advertising campaigns in public areas could be an effective method to increase public awareness. In their study, Gielen et al. ${ }^{18}$, reported that using a kiosk in crowded EDs is an effective method to give information to patients and the suggestions in our study support this result. One of the major suggestions in our study was making strict laws for CSS. As in the use of adult restraints, we know that strict laws can be a disincentive factor if they are strictly enforced and can reduce mortality due to MVC. ${ }^{11}$

\section{Study Limitation}

Our study has some limitations. The first limitation was the low response rate, thus, we could not generalize the results of this study to all physicians. Second, the study was based on the responses of doctors, but we could not assess their knowledge objectively. This could perhaps cause bias in our study results. In spite of overcrowding in EDs, we believe that EDs can be appropriate places to provide information about CSS either by physicians or through visual media. We advocate that making laws and policies about CSS is necessary and should be strictly enforced.

\section{Conclusion}

In conclusion, our survey revealed that physicians, who care for trauma patients, assume that they have high levels of knowledge about CSS. Unfortunately, their knowledge level was as low as in other physicians in the study group.

\section{Ethics}

Ethics Committee Approval: Dokuz Eylül University Medicine Clinical Research Ethics Committee (approval number: 2274 GOA; 2015/21-07).

Peer-review: Externally and internally peer-reviewed.

\section{Authorship Contributions}

Concept: A.Ç., E.U., A.E., M.D., H. Ç, Design: A.Ç., E.U., A.E., M.D., Data Collection or Processing: A.Ç., F.Ç.Ç., B.B., U.K., Analysis or Interpretation: A.Ç., U.K., D.Y., M.D., Literature Search: A.Ç., M.D., Writing: A.Ç.

Conflict of Interest: No conflict of interest was declared by the authors.

Financial Disclosure: The authors declared that this study received no financial support. 


\section{References}

1. CDC Winnable Battles Final Report: Motor Vehicle Injuries. Available at: https://www.cdc.gov/winnablebattles/report/docs/wb-motorvehicles.pdf. Accessed June 14, 2017

2. Sevketoglu E, Hatipoglu S, Esin G, Oztora S. Knowledge and attitude of Turkish parents regarding car safety seats for children. Ulusal travma ve acil cerrahi dergisi=Turkish journal of trauma \& emergency surgery : TJTES 2009;15:482-6.

3. Kanburoglu MK, Cizmeci MN, Akelma AZ, Orun E, Yesilyurt K, et al. Social prejudice hindering proper use of car safety seats. Pediatrics international: official journal of the Japan Pediatric Society 2013;55:798-800.

4. Navarro LD. [What pediatricians should know about car seats?: car safety seats]. Archivos argentinos de pediatria 2013;111:247-50.

5. Yingling F, Stombaugh HA, Jeffrey J, LaPorte FB, Oswanski MF. Pediatricians' knowledge, perceptions, and behaviors regarding car booster seats. Journal of community health 2011;36:166-73.

6. Zonfrillo MR, Sauber-Schatz EK, Hoffman BD, Durbin DR. Pediatricians' self-reported knowledge, attitudes, and practices about child passenger safety. The Journal of pediatrics 2014;165:1040-5 e1-2.

7. Faber MM, Hoppe SK, Diehl AK. Physician knowledge and clinical behavior regarding automobile safety for children. Pediatrics 1985;75:248-53.

8. Zonfrillo MR, Nelson KA, Durbin DR. Emergency physicians' knowledge and provision of child passenger safety information. Academic emergency medicine: official journal of the Society for Academic Emergency Medicine 2011;18:145-51.

9. Macy ML, Clark SJ, Sasson C, Meurer WJ, Freed GL. Emergency physician perspectives on child passenger safety: a national survey of attitudes and practices. Academic pediatrics 2012;12:131-7.
10. Durbin DR. Child passenger safety. Pediatrics2011;127:e1050-66.

11. Centers for Disease Control and Prevention. Injury Prevention \& Control, Web-Based Injury Statistics Query and Reporting System (WISQARS). Available at: https://www.cdc.gov/injury/wisqars/ fatal.html. Accessed June 14, 2017.

12. Rivara FP, Grossman DC. Prevention of traumatic deaths to children in the United States: how far have we come and where do we need to go? Pediatrics 1996;97:791-7.

13. Elliott MR, Kallan MJ, Durbin DR, Winston FK. Effectiveness of child safety seats vs seat belts in reducing risk for death in children in passenger vehicle crashes. Archives of pediatrics \& adolescent medicine 2006;160:617-21.

14. Brixey SN, Guse CE. Knowledge and behaviors of physicians and caregivers about appropriate child passenger restraint use. Journal of community health 2009;34:547-52.

15. Simpson EM, Moll EK, Kassam-Adams N, Miller GJ, Winston FK. Barriers to booster seat use and strategies to increase their use. Pediatrics 2002;110:729-36.

16. Rothenstein J, Howard A, Parkin P, Khambalia A, Macarthur C. Community paediatricians' counseling patterns and knowledge of recommendations relating to child restraint use in motor vehicles. Injury prevention: journal of the International Society for Child and Adolescent Injury Prevention 2004;10:103-6.

17. Morrongiello BA, Howard AW, Rothman L, Sandomierski M. Once bitten, twice shy? Medically-attended injuries can sensitise parents to children's risk of injuries on playgrounds. Injury prevention: journal of the International Society for Child and Adolescent Injury Prevention 2009;15:50-4.

18. Gielen AC, McKenzie LB, McDonald EM, Shields WC, Wang MC, et al. Using a computer kiosk to promote child safety: results of a randomized, controlled trial in an urban pediatric emergency department. Pediatrics 2007;120:330-9. 